University of Pennsylvania Carey Law School

Penn Law: Legal Scholarship Repository

Faculty Scholarship at Penn Law

$11-4-2012$

\title{
The Effect of Privately Provided Police Services on Crime
}

John M. MacDonald

University of Pennsylvania

Jonathan Klick

University of Pennsylvania Carey Law School

Ben Grunwald

University of Pennsylvania

Follow this and additional works at: https://scholarship.law.upenn.edu/faculty_scholarship

Part of the Criminal Law Commons, Criminology Commons, and the Law Enforcement and Corrections Commons

\section{Repository Citation}

MacDonald, John M.; Klick, Jonathan; and Grunwald, Ben, "The Effect of Privately Provided Police Services on Crime" (2012). Faculty Scholarship at Penn Law. 430.

https://scholarship.law.upenn.edu/faculty_scholarship/430

This Article is brought to you for free and open access by Penn Law: Legal Scholarship Repository. It has been accepted for inclusion in Faculty Scholarship at Penn Law by an authorized administrator of Penn Law: Legal Scholarship Repository. For more information, please contact PennlawIR@law.upenn.edu. 
The Effect of Privately Provided Police Services on Crime

\author{
John M. MacDonald* \\ Jonathan Klick** \\ Ben Grunwald*
}

\begin{abstract}
Research demonstrates that police reduce crime. The implication of this research for investment in a particular form of extra police services, those provided by private institutions, has not been rigorously examined. We capitalize on the discontinuity in police force size at the geographic boundary of a private university police department to estimate the effect of the extra police services on crime. Extra police provided by the university generate approximately 45-60 percent fewer crimes in the surrounding neighborhood. These effects appear to be similar to other estimates in the literature.

* University of Pennsylvania, Department of Criminology (johnmm@sas.upenn.edu; ben.grunwald@gmail.com)

** University of Pennsylvania, Law School (jklick@law.upenn.edu)

The authors are grateful to Vice President for Public Safety Maureen S. Rush, Chief of Police Mark Dorsey, John Urban, and Mitchell Yanak for sharing data and institutional knowledge about University of Pennsylvania police operations.
\end{abstract}




\section{Introduction}

Policing accounts for a substantial portion of local government budgets. Local, state, and federal governments spent a total of $\$ 104$ billion on police services in 2007 , at a cost of approximately $\$ 344$ per capita (Kyckelhahn, 2011). Crime reduction is the primary social welfare benefit associated with investing in police. The skepticism among prominent legal scholars and criminologists about the capacity of the police to reduce crime (Gottfredson and Hirschi, 1990; Bayley 1994; Harcourt 2001) has not withstood empirical scrutiny. A number of studies indicate that when police are vigilant (Sampson and Cohen, 1988; MacDonald, 2002), and there are more of them (Levitt, 2002; Zhao et al., 2002; Evans and Owens, 2007), crime drops. The magnitude of the crime drop appears to be greatest in areas of targeted activity, and there is also evidence that targeted areas of police activity may produce larger area benefits such that police are not simply chasing crime around the corner (Di Tell and Schargodsky, 2004; Klick and Tabarrok, 2005; Berk and MacDonald, 2010; Draca et al., 2011; Weisburd et al. 2006). These findings have led several scholars of crime prevention to argue that investing in the police is more sensible than spending on prisons (Durlauf and Nagin, 2011; Cook, Ludwig, and McCrary, 2011).

Despite an abundance of scholarly work on the effects of extra police services on crime, two significant gaps in the empirical literature remain. First, the most methodologically rigorous of these studies have focused on changes in police strength that are exogenous to crime, such as terror events or warnings. As a result, these studies focus on episodic events that are the exception to normal police practices. Less is known about the effect of increasing police force size and deployment over sustained periods of time. There is an important difference between the immediate effect of a "police event" and that of an enduring change in a policing regime. Sherman (1990) suggested that "police crackdowns"-short-term increases in police deployment in targeted areas - show only short-term deterrent effects on crime. We suspect that sustained and long-term investment in additional police deployment exerts a lasting effect on crime, as a permanent increase in police strength is something that will be noticeable to criminals and will reduce the opportunities for easy targets of crime. Thus, there is much to be learned from a study that examines a sustained increase in police activity. 
Second, relatively little is known about the effect of supplemental police services provided by private entities. This observation is surprising given that private security officers significantly outnumber public police officers in the United States. ${ }^{1}$ Individuals, communities, and private institutions often perceive that public police departments provide inadequate security. As a result, they often supplement public police services through protective measures that range in scope from installing LoJack devices in cars and security cameras in stores, to hiring private security or funding additional uniformed police officers (Shearing, 1992). Economists have explored the effect of certain forms of private investment on crime (Ayers and Levitt, 1998; Clotfelter, 1977; Cook and MacDonald, 2011a), but few studies examine the effect of privately funded police agencies. ${ }^{2}$ The role of private police departments in crime reduction is especially pertinent for colleges and universities located in high-crime neighborhoods, which are concerned with the safety of employees and students living in nearby communities.

In this paper, we consider the effect of long-term, supplemental police services provided by a private university on crime in adjacent street blocks. We examine crime over a six-year period in which a private university invested substantial resources on deploying extra uniformed police officers to its adjacent neighborhoods. We use a geographic regression discontinuity design to identify the effects of this extra supply of police on crime. Our results indicate that the additional privately funded police substantially reduce crime, in turn generating benefits that far exceed the cost of maintaining the police force. Our elasticities are consistent with those seen in other work (Di Tella and Schargorosdky, 2004; Klick and Tabarrok, 2005; Berk and MacDonald, 2010; Draca et al., 2011) and suggest that an increase in the size of the police by 200 percent generates a $45-60 \%$ reduction in all reported crimes. The effects are even bigger if we rely on an alternative nonparametric regression discontinuity design.

We begin with a brief review of the literature on the effect of police on crime. This is followed by a more narrow description of how private entities may provide specialized supplements to public police services, and the specific case of how this applies in the

\footnotetext{
${ }^{1}$ In 2007, for example, roughly 950,000 private security officers and only 800,000 public police officers were employed in the United States (Bureau of Labor Statistics, National Employment and Wage estimates, 2007).

${ }^{2}$ Quasi-experimental studies of business improvement districts provide one potential source of insight on the effect of private security. These studies suggest that hiring private security may reduce crime (Brooks, 2008; Cook and MacDonald, 2011b).
} 
Philadelphia context near the University of Pennsylvania. Subsequent sections discuss the data and methods of our analysis, the results and the elasticities based on our estimated crime reductions.

\section{The Effect of Police on Crime}

The raw number of police officers employed in a jurisdiction may be less important than the kinds of crime prevention activities in which they are engaged (Sherman, 1995; Wilson and Boland, 1978; Sampson and Cohen, 1988). That said, the number of police -the proverbial "boots on the ground" - do matter. Levitt (2002) used the hiring of firemen as an instrument for police hiring, and found that additional police officers significantly decrease violent and property crimes. Evans and Owens (2007) examined the relationship between crime and police hiring in cities with over 10,000 residents before and after receiving federal grants to hire additional police officers. They found that hiring police officers is associated with reductions in crime of $2 \%$ to $5 \%$ in both their reduced-form and instrumental variable specifications. ${ }^{3}$ Although the effect size of these estimates may seem small, these are average effects on crime for entire cities and not just the effect of the extra police in the specific neighborhoods in which they were deployed.

Research on the effect of specific police activities in subsections of a city provides even more persuasive evidence of the deterrent effects of police on crime. ${ }^{4}$ Cohen and Ludwig (2002) test the effect of police on crime by exploiting variation in patrol intensity by day of week (Wednesday through Saturday) in two areas of Pittsburgh which received a $25 \%$ to $50 \%$ increase in police patrol over short periods of time. Relying on the timing of the patrol intervention and

\footnotetext{
${ }^{3}$ Similar results are reported by Zhao et al. (2002) in examining a reduced-form model of the effects of COPS grants on crime.

${ }^{4}$ This makes intuitive sense, as research has demonstrated in a number of cities that less than $10 \%$ of city street blocks generate more than half of reported crimes and that most crimes occur during specific days of the week (Sherman, Gartin, and Buerger, 1998; Weisburd et al., 2006). The one early exception to this general observation is the Kansas Police Experiment (Kelling et al., 1974) which randomly assigned three levels of police patrol to 15 beats ( 5 in each group were assigned either no patrol; usual patrol; or 2 to 3 times the usual patrol). Kelling et al., found that additional police on routine patrol had no observable effect on crime. But as the authors note, the study examined the effects of routine patrol and not police manpower or visibility. Subsequent commentators have noted a number of other methodological limitations of the experiment which explain the null findings (see e.g., Sherman \& Weisburd, 1995).
} 
dosage differences across days of the week, Cohen and Ludwig use a difference-in-difference-indifferences design to estimate that days with intensive patrol experienced $34 \%$ and $71 \%$ decreases in average daily gun shots fired and assault-related gun injuries. Klick and Tabarrok (2005) use daily changes in the deployment of police officers due to changes in the terror alert level set by the Department of Homeland Security. The authors found that in Washington, DC, increased police presence is associated with a $6.6 \%$ drop in total crime. Even stronger effects were observed in the Capitol Hill District where the highest numbers of police officers were deployed during terror alerts. Di Tella and Schargrodsky (2004) conducted a similar quasiexperimental design, but focused on street blocks rather than days of the week. Following a terrorist attack on a Jewish center in Buenos Aires in 1994, the police deployed additional patrols to areas of the city with Jewish institutions. Assuming that the resulting geographic allocation of patrols was exogenous to crime, Di Tella and Schargrodsky compare the rate of car thefts before and after the attack in areas with and without Jewish institutions. After the attack, car thefts dropped by $75 \%$ on street blocks with a Jewish institution relative to street blocks without a Jewish institution. They found no effect on car thefts just one or two blocks away from Jewish institutions, suggesting that the deterrent effect of police deployment is highly localized. Draca et al. (2011) recently examined the effects of police on crime by comparing changes in crime before and after a terrorist bombing in London, which resulted in the immediate deployment of supplementary police officers to central London. The rest of London did not receive the increase in officers. They also have the benefit of a research design that can examine what happens after the extra deployment to central London is lifted. Their difference-in-differences design shows that a $10 \%$ increase in police deployment reduced crime in central London by 3 to $4 \%$. Berk and MacDonald (2010) use a similar quasi-experimental design to test the effects of a police crackdown in downtown Los Angeles by comparing crime rates before and after the additional deployment in downtown Los Angeles relative to adjacent police divisions. They observe a 30$39 \%$ relative reduction in crimes associated with the extra police officers.

In addition to the quasi-experimental literature described above, there is also a body of field experiments in criminology that tests the effect of supplementary deployment to high crime "hot spots." Sherman and Weisburd (1995) identify the 110 highest crime street blocks in Minneapolis, MN and randomly assigned 55 of these blocks to receive a "crackdown-back off" deployment pattern in which police cars spent as much as one extra hour per shift in each of the 
treatment areas. The study found that treatment areas experienced a $6 \%$ to $13 \%$ relative reduction in crime compared to control areas, with the largest effects observed for disorder crimes. Other field experiments have also found that targeted police patrols in high crime areas reduce crime and disorder (Weisburd and Green, 1995; Braga et al., 1999; Braga and Bond, 2008). These studies all focus on highly localized areas for short durations in time. They do not rule out the possibility that police deployment displaces crime to adjacent areas. There is little empirical evidence that supports the displacement hypothesis (Weisburd et al., 2006), but with any small-scale field experiment it is possible that the positive local effects are being offset by shifting crime to other areas not observed.

This review of the empirical literature provides strong evidence that the size of the police and their deployment produces substantial social welfare benefits. However, the existing empirical literature on the effect of police activities is largely idiosyncratic and short-term; it focuses on rare spikes in police deployment due to terror events, or police crackdowns. These designs fail to measure the effect of sustained increases in deployment. Research on police crackdowns, for example, implies that their deterrent effect would dissipate over time if they became a permanent fixture of police department tactics. Moreover, it is possible that crime reductions associated with short-term terrorism-related deployment may derive from increased officer vigilance or alertness. It is unlikely this increased level of vigilance could be maintained for long periods of time without further risk of terrorist events. Thus, relatively little is known about the sustained effect of normal police deployments over long periods of time.

\section{Privately Funded Police and the University of Pennsylvania}

The University of Pennsylvania (Penn) maintains the largest privately funded publicly certified police department in the Pennsylvania, employing roughly 100 full-time sworn police officers. The department is the third largest university police department in the United States (Reaves, 2008). The primary role of the University of Pennsylvania Police Department (UPPD) is crime prevention within and around the Penn campus. Figure 1 depicts three key geographic areas to which we refer throughout the remainder of the paper. First, the Inner Penn Campus, demarcated by a thick line, refers to the campus proper; it primarily includes residential dormitories, classroom buildings, administrative university offices, restaurants and stores. 
Second, the Outer Penn Campus, demarcated by the finer line, encompasses the neighborhood adjacent to the Inner Penn Campus (between 30th and 43rd Streets and between Market Street and Baltimore Avenue). Many students, faculty, and other Philadelphia residents live in this area. Third, Inner Penn Campus and Outer Penn Campus are both located within the larger University City District, which is demarcated by the dotted line in Figure 1. The University City District is a special services district established by the University to "coordinate sanitation, security, and other services and to promote the area's residential retail assets" (Kromer \& Kerman, 2004). UPPD deploys police officers on foot, bike and mobile patrols to both the Inner Penn Campus, and the Outer Penn Campus. We refer to this area as the Penn Patrol Zone. At any given time, at least sixteen UPPD police officers are on patrol within the Penn Patrol Zone, which supplement the existing Philadelphia Police Department for the entire University City District, including the Penn campus. ${ }^{5}$ The UPPD does not deploy officers to areas of the University City District outside of the inner and outer campus areas; this area is served exclusively by the Philadelphia Police Department.

The UPPD is a sizable investment in extra police in the Penn Patrol Zone (Inner and Outer Penn Campus). The entire University City District in which the Penn campus is situated has only six to eight Philadelphia Police Department patrol officers on duty at any given time. In short, Penn is supplying many more police officers than would otherwise be deployed in the adjacent neighborhoods. In this study, we exploit the substantial difference in policing force size across the Penn patrol boundary to estimate the effect of these extra privately funded police on crime.

\footnotetext{
${ }^{5}$ The training for UPPD is similar to the city of Philadelphia Police Department, and a number of officers have served in both agencies. The department also maintains a Detective Bureau responsible for conducting criminal investigations, crime scene management and evidence collection for crimes throughout patrol zone.
} 
Figure 1: University City District Crime Patterns and Outer Penn Patrol Boundary

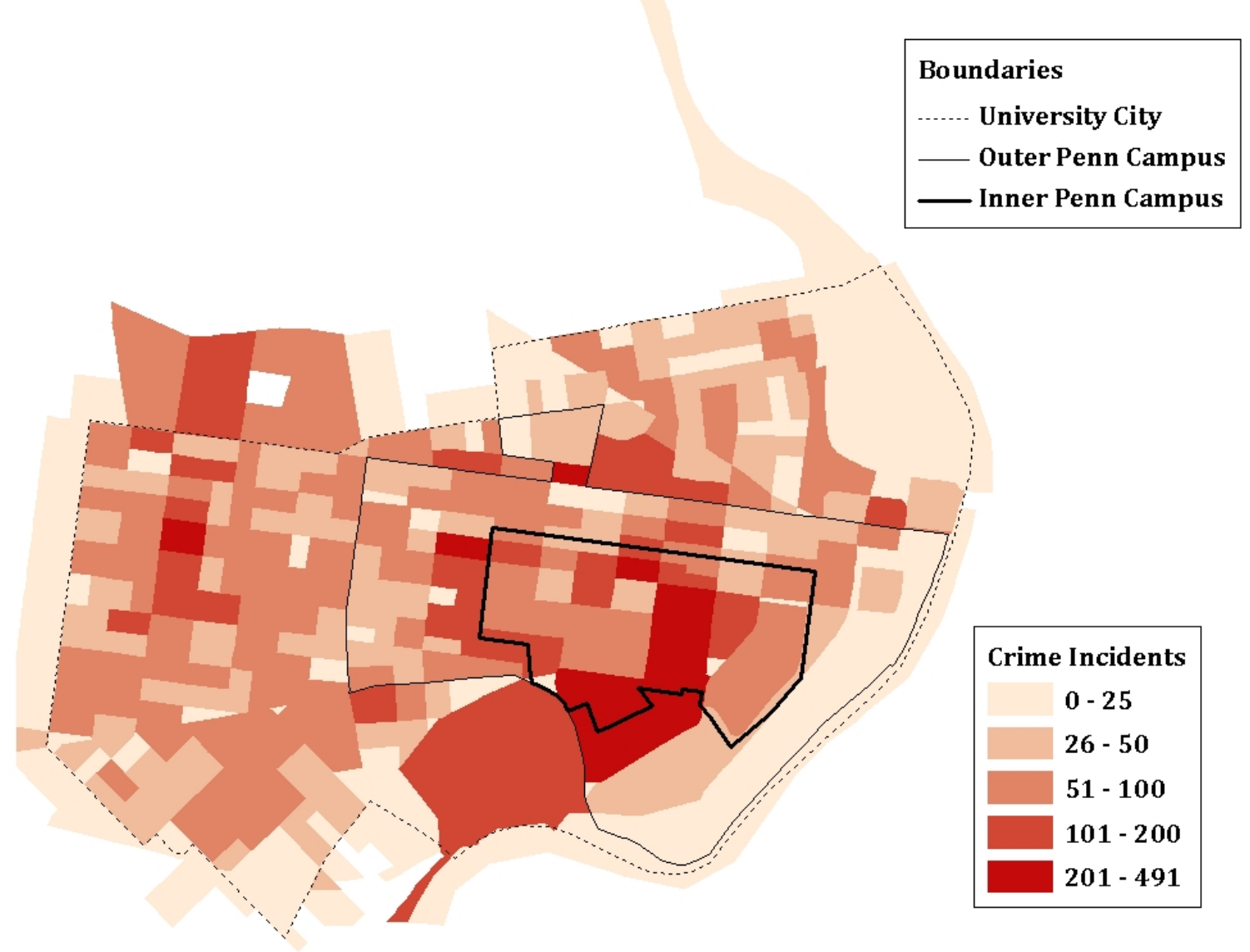

\section{Data and Descriptive Statistics}

We obtained detailed reports of every crime reported in the University City District between 2005 and 2010. We classify crimes into four categories: total crimes, violent crimes (assaults, murder, rape, and robbery), property crimes (all non-violent offenses), and street crimes (assaults, burglaries, purse snatch, robberies, theft from vehicles). We created the street crime classification because these offenses are more likely to occur in the direct visibility of police patrols. 
The crime data includes detailed address locations for 19,611 crimes. $^{6}$ Using GIS software, we calculated the distance between the location of each crime and the UPPD boundary. ${ }^{7}$ We then averaged these distances within each of the 398 city blocks in the sample to estimate the distance of each block from the boundary. For the four blocks where no crimes occurred in the sample period, we used the distance from the block's centroid to the UPPD boundary. ${ }^{8}$ Crimes inside the Penn Patrol Zone are assigned a negative distance value and crimes outside the Penn Patrol Zone are assigned a positive value. Crimes on the boundary (e.g., at 40th and Market) are assigned a distance of zero and are, thus, included within the Penn Patrol boundary.

Incident data were then aggregated up to the block level. A small number of blocks were split across both sides of the Penn Patrol boundary, and were thus treated as two separate blocks for the purpose of our analysis. We aggregate without consideration for time (i.e., collapse six years of data into a single cross section) because the source of our identifying variation, the patrol boundary, does not vary temporally. Of the 398 census blocks located with University City District, 148 fall within the UPPD patrol boundary.

Table 1 shows that during the six-year period for which data are available there were an average of 71 crimes per block in the Inner Penn and 40 in the Outer Penn Campus. The bulk of these crimes were property offenses, especially thefts from buildings. Blocks in the Outer Penn Campus experienced higher rates of street crime, as do blocks outside located in the University District outside of the Outer campus. This descriptive comparison does not take into consideration that blocks further away from the campus are different in many respects (e.g., public housing complexes) from blocks closer to campus. It is, therefore, not plausible to generate causal inference from this simple description of the crime data.

\footnotetext{
${ }^{6}$ Crimes reported include aggravated assault, aggravated assault with guns, assault, auto theft, bike theft, burglary, homicide, homicide with gun, purse snatch, retail theft, robbery, robbery with gun, and sex offense, theft, theft from building, theft from vehicle. Twenty-three of these cases fall outside of the University City District and are excluded from the analysis, leaving the total count of analyzed crimes to 19,588 .

${ }^{7}$ We received the geographic information on the boundaries from the UPPD. See http://www.publicsafety.upenn.edu/assets/General-Web-Photos/PennPatrolpdf.pdf.

${ }^{8}$ Our results are qualitatively similar if we use the centroid measurement for all blocks.
} 
Table 1: Descriptive Statistics of Crime by Boundary

Inner Penn Zone

\begin{tabular}{|l|c|c|c|c|c|}
\hline Variable & $\mathrm{N}$ & Mean & SD & Min & Max \\
\hline All Crime & 43 & 71.8 & 81.1 & 1 & 341 \\
\hline Violent & 43 & 8.9 & 10.4 & 0 & 55 \\
\hline Property & 43 & 62.0 & 73.3 & 0 & 293 \\
\hline Street Crime & 43 & 12.3 & 11.3 & 0 & 50 \\
\hline Distance & 42 & -1025 & 291 & -1573 & -208 \\
\hline
\end{tabular}

Outer Penn Zone

\begin{tabular}{|l|c|c|c|c|c|}
\hline Variable & $\mathrm{N}$ & Mean & SD & Min & Max \\
\hline All Crime & 105 & 40.2 & 46.9 & 1 & 309 \\
\hline Violent & 105 & 9 & 11.3 & 0 & 47 \\
\hline Property & 105 & 31.2 & 39.1 & 0 & 271 \\
\hline Street Crime & 105 & 17.7 & 14.9 & 0 & 58 \\
\hline Distance & 105 & -321 & 345 & -1185 & 0 \\
\hline
\end{tabular}

University City District (excluding Inner and Outer Penn Zone)

\begin{tabular}{|l|c|c|c|c|c|}
\hline Variable & N & Mean & SD & Min & Max \\
\hline All Crime & 251 & 49 & 49.0 & 1 & 626 \\
\hline Violent & 251 & 14.9 & 14.9 & 0 & 257 \\
\hline Property & 251 & 34.1 & 34.1 & 0 & 369 \\
\hline Street Crime & 251 & 31.3 & 31.3 & 0 & 410 \\
\hline Distance & 251 & 1424 & 1424 & 1 & 3952 \\
\hline
\end{tabular}




\section{Regression Discontinuity Design}

Regression discontinuity designs provide the opportunity to draw causal inferences from non-experimental data when appropriately identified. Hahn, Todd, and Van der Klaauw (2001) and Lee (2008) show that the identifying assumptions in a regression discontinuity design are relatively weak in comparison to other standard approaches in empirical microeconomics. In our context, the primary requirement is the absence of systematic differences relevant to crime between areas just inside and just outside of the Penn patrol boundary.

The Penn patrol boundary constitutes an effective geographic discontinuity. The boundary is, in many respects, a historical artifact. The University of Pennsylvania's strategy since the mid-1990s has been to merge the university and the surrounding neighborhood, investing heavily in infrastructure, including housing, retail establishments, and primary schooling options for local residents (Kromer and Kerman, 2004; Rodin, 2005). As a result, much of the surrounding neighborhood is populated by Penn students and faculty making it largely indistinguishable from the part of the neighborhood that is within the Penn patrol boundary. Many, if not most, Penn faculty, students, and staff members are unaware of the location of the patrol boundary, highlighting what has become a seamless relationship between Penn and the University City District. Penn also provides many services, such as transit services, well beyond the formal campus boundary. The university also administers a housing subsidy program that is meant to induce faculty to live in West Philadelphia, beyond the campus border.

For our purposes, however, it is important that there is a policy relevant discontinuity created by the boundary. Specifically, as discussed above, there is a significantly higher police presence protecting those blocks within the boundary than those outside of it.

In our initial analyses, we exclude the Inner Penn Campus because it is composed of classroom buildings, university office space, dormitories, a hospital, and sports facilities, making it less comparable to the residential and retail areas that exist on either side of the Outer Campus boundary. As shown later, this exclusion does not affect our analysis.

Following Lee (2008), we use a polynomial regression specification where we control for the distance from the city block to the campus boundary. Blocks inside the boundary are assigned negative distance values and blocks outside of the boundary are assigned positive values. We allow these control terms to take the form of nth degree polynomials that differ 
depending on whether the given city block is inside or outside of the boundary (i.e., each polynomial term is interacted with a dummy variable indicating whether the block is inside the boundary). The average estimated crime conditional the extra university police is estimated as follows:

$$
\text { Crime }_{i}=\mu+W_{i}^{*} \alpha+\theta \sum_{k=1}^{4} U P P D^{*} d_{i}^{n}+\rho \sum_{k=1}^{4} U C D^{*} d_{i}^{n}+v_{i}
$$

The variable $W$ is a dummy indicator that assumes value 1 for each block (denoted i) inside the patrol zone boundary, and the terms $\theta$ and $\rho$ represent quartic degree ( $n=1$ to 4 ) polynomial parameters for the inside (UPPD) or outside (UCD) average block distances (denoted by d) for crimes on blocks from the boundary. This polynomial specification is flexible, since it is well known in the RD literature that the assumption of a constant treatment effect continuously away from the cutoff is not identifiable (Cook, 2008; Hahn, Todd, and Van der Klaauw, 2001). Standard errors are also corrected for dependence within blocks using a cluster sandwich estimator. As in Lee (2008), we focus on the specification using a quartic function allows for differing effects of this function depending on whether the block is inside or outside the boundary. However, we used k-fold cross validation techniques to examine the sensitivity of model performance to this choice, finding little difference in model performance across polynomial functions of orders zero through five. Further, inspection of the estimated treatment coefficients yielded few differences even through a polynomial of order 10 .

Table 2 provides results ${ }^{9}$ comparing blocks inside and outside the Penn Patrol Zone boundary, excluding the Inner Penn Campus. While crime is generally lower in the Penn campus, as shown in column i which does not control for any distance effects, once we use the polynomial function of distance to isolate the relevant comparable areas inside and outside the boundary, we find that there are 27 fewer crimes on each block inside the boundary as compared to the counterfactual blocks outside the boundary. This effect is statistically significant at the 1 percent level, and it represents a relative reduction of 56 percent.

\footnotetext{
${ }^{9}$ We present the results from ordinary least squares regressions. The results are effectively the same if we exploit the count nature of the data, estimating negative binomial or Poisson models. We obtain similar results if we examine log crime as well.
} 


\begin{tabular}{|c|c|c|c|}
\hline \multicolumn{4}{|c|}{$\begin{array}{l}\text { Table 2: The Effect of Penn Police on } \\
\text { (robust standard errors in parentheses) } \\
\\
\end{array}$} \\
\hline & (i) & (ii) & (iii) \\
\hline Penn Campus & $\begin{array}{l}-8.22 \\
(5.51)\end{array}$ & $\begin{array}{l}-21.00 * * * \\
(6.87)\end{array}$ & $\begin{array}{l}-27.04 * * * \\
(9.47)\end{array}$ \\
\hline $\begin{array}{l}\text { Distance to Campus } \\
\text { Border Effect }\end{array}$ & None & $\begin{array}{l}\text { Linear interacted with } \\
\text { Penn and UCD } \\
\text { indicators }\end{array}$ & $\begin{array}{l}\text { Quartic interacted } \\
\text { with Penn and UCD } \\
\text { indicators }\end{array}$ \\
\hline $\begin{array}{l}\text { Inner-Penn Campus } \\
\text { Included }\end{array}$ & No & No & No \\
\hline Percentage Change & $-17 \%$ & $-44 \%$ & $-56 \%$ \\
\hline \multicolumn{4}{|c|}{$\begin{array}{l}\text { Note: Results estimated using ordinary least squares regression. Blocks within the inner Penn } \\
\text { campus are excluded. For all regressions, } \mathrm{n}=356 . \\
* * * \mathrm{p}<0.01 \\
* * \mathrm{p}<0.05 \\
* \mathrm{p}<0.10\end{array}$} \\
\hline
\end{tabular}

Figure 2 shows the relationship between average block distance to the boundary, and the total number of crimes over the period observation. As is evident from Figure 2, the patterns of crime are non-linear as the distance from the patrol zone boundary increases and there is apparent higher density of crimes as one gets to further distances away. The drop in crime at the border is a visual depiction of our point estimate. Again, we note that the location of this boundary was largely a historical accident, and there is no simple explanation for the drop in crime at the boundary other than the location of extra UPPD police. 
Figure 2: Crime by Block Distance from Patrol Boundary

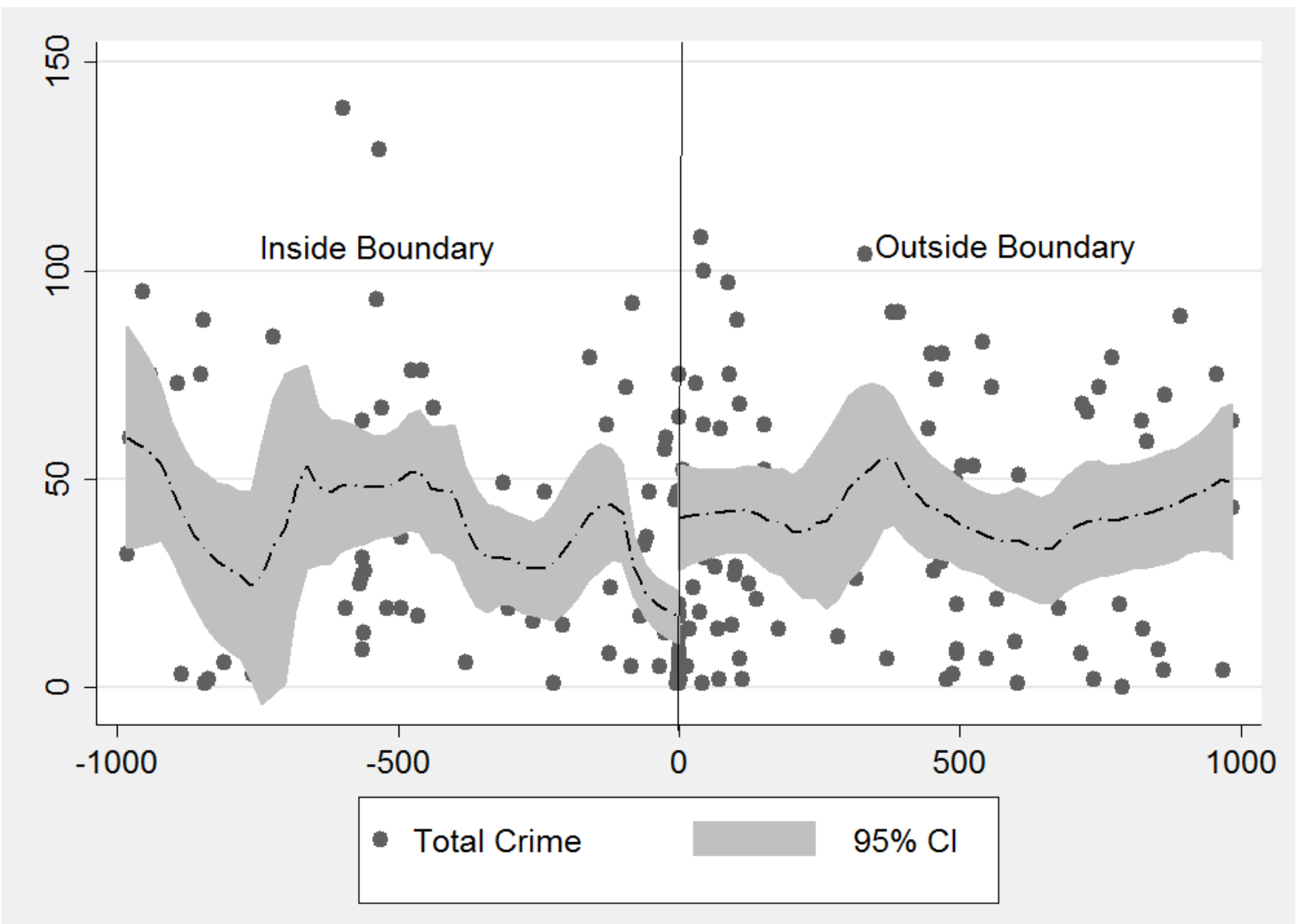

In Table 3, we examine the effect of Penn's increased policing separately by crime category. For each category, the estimated coefficient is negative and statistically significant at the 5 percent level or lower. The magnitude of the effects is comparable across crime categories. Violent crime is 60 percent lower, property crime is 55 percent lower, and street crime is 46 lower inside of the Penn patrol boundary. 


\begin{tabular}{|c|c|c|c|}
\hline & Violent & Property & Street \\
\hline Penn Campus & $\begin{array}{l}-8.74 * * \\
(3.59)\end{array}$ & $\begin{array}{l}-18.31 * * \\
(7.07)\end{array}$ & $\begin{array}{l}-14.14 * * * \\
(3.64)\end{array}$ \\
\hline $\begin{array}{l}\text { Distance to Campus } \\
\text { Border Effect }\end{array}$ & $\begin{array}{l}\text { Quartic interacted } \\
\text { with Penn and UCD } \\
\text { indicators }\end{array}$ & $\begin{array}{l}\text { Quartic interacted } \\
\text { with Penn and UCD } \\
\text { indicators }\end{array}$ & $\begin{array}{l}\text { Quartic interacted } \\
\text { with Penn and UCD } \\
\text { indicators }\end{array}$ \\
\hline $\begin{array}{l}\text { Inner-Penn Campus } \\
\text { Included }\end{array}$ & No & No & No \\
\hline Percentage Change & $-60 \%$ & $-55 \%$ & $-46 \%$ \\
\hline \multicolumn{4}{|c|}{$\begin{array}{l}\text { Note: Results estimated using ordinary least squares regression. Blocks within the inner Penn } \\
\text { campus are excluded. For all regressions, } \mathrm{n}=356 . \\
* * * \mathrm{p}<0.01 \\
* * \mathrm{p}<0.05 \\
* \mathrm{p}<0.10\end{array}$} \\
\hline
\end{tabular}

Given the nature of the polynomial regression discontinuity design, including observations relatively far from the discontinuity point should not influence the estimated treatment effects if the model is well identified. This issue of appropriate identification, coupled with the institutional knowledge that the Inner Penn Campus is substantively different than the areas around the boundary led us to exclude the 42 blocks in the Inner Penn Campus from our analysis. However, to ensure that our model is well identified, we present results in Table 4 that include the blocks in the Inner Penn Campus. In each crime category, our results exhibit trivial changes at most. 


\begin{tabular}{|c|c|c|c|}
\hline & Violent & Property & Street \\
\hline Penn Campus & $\begin{array}{l}-8.74 * * \\
(3.57)\end{array}$ & $\begin{array}{l}-20.16^{* * *} \\
(7.07)\end{array}$ & $\begin{array}{l}-13.73 * * * \\
(3.64)\end{array}$ \\
\hline $\begin{array}{l}\text { Distance to Campus } \\
\text { Border Effect }\end{array}$ & $\begin{array}{l}\text { Quartic interacted } \\
\text { with Penn and UCD } \\
\text { indicators }\end{array}$ & $\begin{array}{l}\text { Quartic interacted } \\
\text { with Penn and UCD } \\
\text { indicators }\end{array}$ & $\begin{array}{l}\text { Quartic interacted } \\
\text { with Penn and UCD } \\
\text { indicators }\end{array}$ \\
\hline $\begin{array}{l}\text { Inner-Penn Campus } \\
\text { Included }\end{array}$ & Yes & Yes & Yes \\
\hline Percentage Change & $-60 \%$ & $-60 \%$ & $-45 \%$ \\
\hline \multicolumn{4}{|c|}{$\begin{array}{l}\text { Note: Results estimated using ordinary least squares regression. Blocks within the inner Penn } \\
\text { campus are included. For all regressions, } \mathrm{n}=398 . \\
* * * \mathrm{p}<0.01 \\
* * \mathrm{p}<0.05 \mathrm{~h} \\
* \mathrm{p}<0.10\end{array}$} \\
\hline
\end{tabular}

Table 5 provides results for each individual crime type. While there is some variation in the relative effects across specific crimes, the treatment effects are generally negative and substantively important. There are four exceptions. We do not find a negative effect for handgun-homicides, purse snatchings, or thefts from buildings, though none of these positive effects can be distinguished from the null hypothesis of no difference. It is worth noting that handgun-homicides and homicides that are the result of other means are rare events, accounting for only $0.15 \%(n=31)$ of all crimes. Purse snatchings are also relatively rare $(0.55 \% ; n=55)$ and occur mostly along central business corridors. Theft from buildings is not a street crime that is easily detectable by police patrols. 
Table 5: The Relative Effect of Penn Police by Specific Crime Type

\begin{tabular}{|c|c|}
\hline $\mathrm{Ag}=$ aggravated assault & $-78 \% * *$ \\
\hline Aggun $=$ aggravated assault with gun & $-45 \% *$ \\
\hline As $=$ assault & $-63 \%$ \\
\hline $\mathrm{Au}=$ auto theft & $-51 \% * * *$ \\
\hline Bike $=$ bike theft & $-42 \%$ \\
\hline Burg = burglary & $-42 \% * * *$ \\
\hline Hgun $=$ Hand gun homicide & $104 \%$ \\
\hline Hom $=$ Homicide & $-93 \%$ \\
\hline Purse $=$ Purse Snatching & $7 \%$ \\
\hline Rob $=$ Robbery & $-64 \% * *$ \\
\hline Robgun $=$ Robbery Gun & $-37 \% * * *$ \\
\hline Sex $=$ Sexual Assault & $-71 \%$ \\
\hline Theftb $=$ Theft from Building & $26 \%$ \\
\hline Theftmv $=$ Theft from Motor Vehicle & $-44 \% * * *$ \\
\hline Theftr $=$ Theft from Retail & $-266 \% * *$ \\
\hline Theft $=$ Other Theft & $-50 \%$ \\
\hline \multicolumn{2}{|c|}{$\begin{array}{l}\text { Note: Results estimated using ordinary least squares regression. Each coefficient is estimated } \\
\text { by a separate regression that includes distance to the boundary of Penn's campus as a quartic } \\
\text { interacted with Penn and UCD indicators. These regressions are estimated on samples that } \\
\text { exclude blocks within the inner Penn campus. Percentage changes are calculated relative to the } \\
\text { UCD averages for each crime type and robust standard errors are used. For all regressions, n= } \\
356 \text {. }\end{array}$} \\
\hline
\end{tabular}


Figure 3 provides a graphical depiction of the point estimates in Table 5. One can clearly see that the majority of crimes are lower in blocks inside the Penn patrol boundary.

Figure 3: Graphical Depiction of Point Estimates.

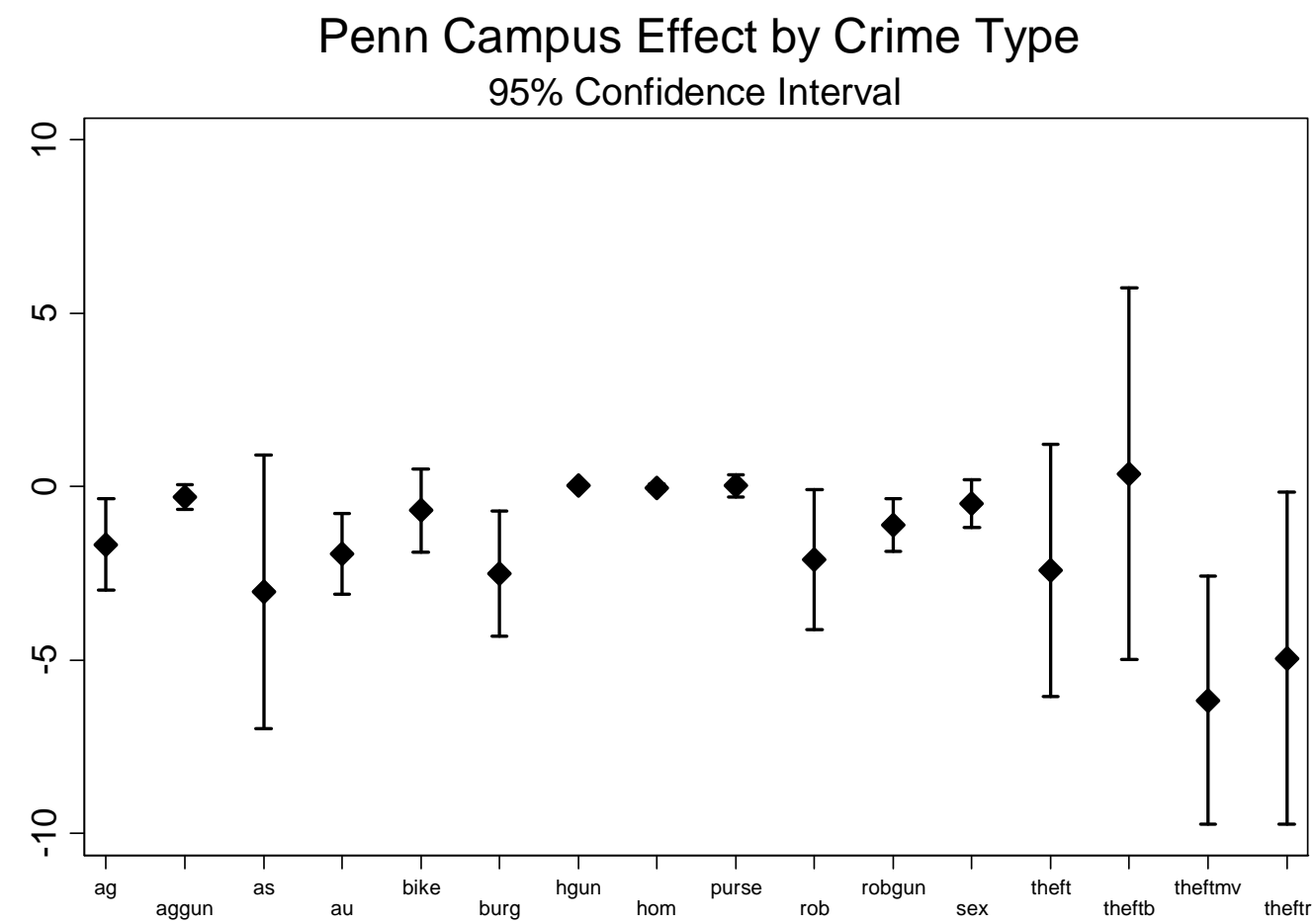

Our results paint a fairly consistent picture. Comparing seemingly similar blocks on either side of an arbitrary boundary which increased police patrols do not cross, we find that more police protection is associated with lower crime. This effect is statistically and practically significant across nearly all crime categories. It is also largely invariant to the choice of regression specification, and the inclusion of data points farther from the discontinuity.

While we have focused on a polynomial based regression discontinuity approach, kernel based approaches provide similar conclusions. Using Imbens and Kalyanaraman's approach (2011), which optimizes the tradeoff between statistical efficiency and bias in determining threshold bandwidth, we find even larger crime reductions inside the Penn boundary, on the order of 85 percent. While we prefer to focus on the more conservative estimates detailed above, even those larger effect estimates may be understated. 


\section{Elasticity Estimates}

Personnel estimates from both the Philadelphia Police Department and the UPPD indicate that approximately twice as many officers patrol the Outer Penn Zone than the surrounding University City District. The area covered by Philadelphia Police is twice as big as that covered by the Penn Police, suggesting an effective increase in police presence on the order of 200 percent. Our estimate that UPPD activity is associated with a 60 percent reduction in crime suggests that the elasticity of crime with respect to police is about -0.30 for both violent and property crimes.

These elasticity estimates are strikingly similar to those found in the modern literature on police and crime. Chalfin and McCrary's (2012; Table 8) recent paper provides a helpful summary of these previous estimates. Klick and Tabarrok (2005), Draca, Machin, and Witt (2011) and Di Tella and Schargrodsky (2004) - all of which use an exogenous shock in police deployment resulting from terrorism-related events - find an elasticity of approximately -0.30 . Our study suggests that the results of these earlier studies are not driven by some background change that accompanies fears of terrorism or an increase in diligence on the part of police when working during such times. Our results are also similar to those presented in Berk and MacDonald (2010) who examine a police crackdown in Los Angeles and find similar elasticities. The results from our investigation help answer concerns that short-term gains from police crackdowns are not sustainable. Instead, our results suggest that these crackdown studies may be generalizable if extra police presence becomes a permanent feature of an area.

Our results are also consistent with the other longer term estimates found in the modern literature. For example, Evans and Owens (2007) who examine police staffing increases related to a federal grant program over an eight year period find an elasticity of property crimes of -0.26 , though their violent crime elasticity is much higher. Chalfin and McCrary's (2012) study of crime in US cities over the period 1960-2010, which corrects for the measurement error bias that may exist in prior studies, finds a violent crime elasticity of -0.35 , though their property crime elasticity is only -0.15 . They suggest, however, that their results may understate the true magnitude of the elasticity due to simultaneity bias because they lack plausibly exogenous variation in their police measures. Cities tend to hire more police when they expect crime to 
increase, and as a result, panel data models tend to underestimate the elasticity of police on crime.

Our results also suggest that privately employed police forces generate reductions in crime that are comparable to those associated with public police forces. While the UPPD employs publicly certified law enforcement officers, their salaries are paid for directly by a private university. These findings suggest that augmenting public police forces with substantial private investments can have a meaningful effect on crime rates. Chalfin and McCrary (2012) provide one of the more rigorous estimates of the cost of crime relative to the hiring of police. They find that in a typical U.S. city, investing a dollar in police hiring yields an average of $\$ 1.50$ in benefits to the public. From these estimates we can say that the benefits of paying for UPPD services are a large multiple of the costs of employing the extra police. ${ }^{10}$

\section{Conclusion}

Given the importance of police protection for private firms and the tremendous welfare effect of crime in city neighborhoods, the lack of prior studies on the effects of extra police provided by universities is an important omission. Although others before us laid the groundwork for assessing the causal effect of the police more generally on crime, and their influence on crime when deployed to high crime areas, we provide one of the first examinations of the crime reduction effects of supplemental police services provided on a large-scale by a university on its surrounding neighborhood.

While this study provides a credible estimate of the effect of the UPPD on crime, more research is needed to determine if this effect could be generalized to other settings where universities are located in urban cities. In particular, the geographic discontinuity design we employ could be used in other settings as universities plan to expand their patrol boundaries to provide extra police services to off-campus neighborhoods.

Our identification strategy would be undermined if the Penn patrol boundary was selected because it reflects some natural geographic discontinuity of student living or commercial properties that the university is particularly interested in protecting. To the best of our

\footnotetext{
${ }^{10}$ The costs of salary and benefits for a new UPPD officer is $\$ 62,650$, which is comparable to the starting salary $(\$ 45,420$ ) and benefits (assuming $40 \%$ ) for the Philadelphia Police is $\$ 63,588$.
} 
knowledge, the patrol zone was selected as part of a negotiation with the University City District, and there is no evidence that the zone is anything but an attempt to secure the outer ring of the campus and off-campus properties that are considered valuable to the university (Rodin, 2007). Fundamentally, there is no reason to think that the demographic or risk profile shifts fundamentally at 2 to 3 blocks beyond the boundary in the University City District. A large number of university students live as far as 50th street, suggesting that street blocks have similar exposure to student risk groups within our bandwidth. The hiring of additional police services appears to be an effective approach to reducing crime. 


\section{References}

Ayres, Ian, Levitt Steven D., 1998. Measuring Positive Externalities from Unobservable Victim Precautions: An Empirical Analysis of Lojack. Quarterly Journal of Economics 113 (1), 43-77.

Berk, Richard, MacDonald, John M., 2010. Policing the Homeless: An Evaluation of Efforts to Reduce Homeless-Related Crime. Criminology and Public Policy 9 (4), 813-840.

Braga, Anthony A., Weisburd, David L., Waring, Elin J., Mazerolle, Lorraine Green, Spelman, William, Gajewski, Francis, 1999. Problem-oriented policing in violent crime places: A randomized controlled experiment. Criminology 37 (3), 541-80.

Braga, Anthony A., Bond, Brenda J., 2008. Policing Crime and Disorder Hot Spots: A Randomized Controlled Trial. Criminology 46 (3), 577-608.

Brooks, Leah, 2008. Volunteering to be taxed: Business improvement districts and the extragovernmental provision of public safety. Journal of Public Economics 92, 388-406.

Cameron A.C., Trivedi P.K., 1998. Regression analysis of count data. Cambridge, UK:

Cambridge University Press.

Chalfin, Aaron, McCrary, Justin, 2012. The Effect of Police on Crime: New Evidence from U.S. Cities, 1960-2010. NBER Working Paper.

Clotfelter, Charles T, 1977. Public services, private substitutes, and the demand for protection against crime. American Economic Review 67 (5), 867-877.

Cohen, Jacqueline, Ludwig, Jens, 2003. Policing Crime Guns. Evaluating Gun Policy. Jens

Ludwig and Philip J. Cook, ed. Washington, DC: Brookings, 217-250.

Cook, P.J, Ludwig, J., McCrary, J., 2011. Controlling Crime: Strategies and Tradeoffs. Chicago: University of Chicago Press. 
Cook, T., 2008. Waiting for Life to Arrive: A history of the regression-discontinuity design in Psychology, Statistics and Economics. Journal of Econometrics 142 (2), 636-654.

Di Tella, Rafael, and Schargrodsky, Ernesto, 2004. Do Police Reduce Crime? Estimates Using the Allocation of Police Forces After a Terrorist Attack. American Economic Review 94(1), 115133.

Draca, Mirko, Machin, Stephen, Witt, Robert, 2011. Panic on the Streets of London: Police, Crime, and the July 2005 Terror Attacks: Dataset. American Economic Review 101 (5), 21572181.

Durlauf, Steven N., Nagin, Daniel S., 2011. Imprisonment and Crime. Criminology and Public Policy, 10 (1), 13-54.

Evans, W., Owens, E, 2007. COPS and crime. Journal of Public Economics 91 (1-2), 181-201.

Gottfredson, Michael R., Hirschi, Travis, 1990. A General Theory of Crime. Stanford: Stanford University Press.

Hahn, Jinyong, Todd, Petra, Van der Klaauw, Wilbert, 2001. Identification and Estimation of Treatment Effects with a Regression-Discontinuity Design. Econometrica, 69 (1), 201-209.

Imbens, G., Kalyanaraman, K., (Forthcoming). Optimal Bandwidth Choice for the Regression Discontinuity Estimator. Review of Economic and Statistics.

Kelling, G., Pate, A.M., Dieckman, D., Brown, C., 1974. The Kansas City Preventative Patrol Experiment: Technical Report. Washington, DC: Police Foundation.

Kromer, John, Kerman, Lucy, 2004. A Case Study in Urban Revitalization. Available at: http://www.fels.upenn.edu/news/new-report-urban-revitalization-1.

Kyckelhahn, T., 2011. Justice Expenditures and Employment, FY 1982-2007 - Statistical Tables. Washington, DC: Bureau of Justice Statistics, U.S. Department of Justice. NCJ 236218.

Klick, Jonathan, Tabarrok, Alexander, 2005. Using Terror Alert Levels to Estimate the Effect of Police on Crime. The Journal of Law and Economics, 48, 267-279. 
Lee, David S., 2008. Randomized Experiments from Non-random Selection in U.S. House Elections. Journal of Econometrics 142 (2), 675-697.

Levitt, Steven, 2002. Using Electoral Cycles in Police Hiring to Estimate the Effects of Police on Crime: Reply. American Economic Review 92 (4), 1244-50.

MacDonald, John M., 2002. The Effectiveness of Community Policing in Reducing Urban Violence. Crime and Delinquency 48 (4), 592-618.

Reaves, B., 2008. Campus Law Enforcement, 2004-05. Washington, DC: Bureau of Justice Statistics, U.S. Department of Justice. NCJ 219374.

Rodin, Judth, 2005. The $21^{\text {st }}$ Century Urban University: New Roles for Practice and Research. Journal of the American Planning Association 71 (3), 237-249.

Sampson, R. J., Cohen, J., 1988. Deterrent effects of the police on crime: A replication and theoretical extension. Law and Society Review 22 (1), 163-189.

Sherman, L., Weisburd, D, 1995. General deterrent effects of police patrol in crime hot spots: A randomized controlled trial. Justice Quarterly 12, 625-648.

Sherman. L.W., 1990. Police Crackdowns: Initial and Residual Deterrence. In M. Tonry and N.Morris (eds.) Crime and Justice: An Annual Review of Research, 12, 1-48.

Weisburd, David L., Green, Lorraine, 1995. Policing drug hot spots: The Jersey City DMA experiment. Justice Quarterly 12 (4), 711-36.

Weisburd, D., Wyckoff, L.A., Ready, J., Eck J.E., Hinkle, J.C., Gajewski, F., 2006. Does Crime Just Move Around the Corner? A Controlled Study of Spatial Displacement and Diffusion of Crime Control Benefits. Criminology 44 (3), 549-9.

Wilson, J. Q., Boland, B., 1978. The effect of the police on crime. Law and Society Review 12 (3), 367-390. 
Zhao, J., Scheiher, M. C., Thurman, Q., 2002. Funding Community Policing to Reduce Crime: Have COPS Grants Made a Difference? Criminology \& Public Policy 2 (1), 7-32. 